\title{
Diversity of endophytic fungi from the root bark of Syzygium zeylanicum, and the antibacterial activity of fungal extracts, and secondary metabolite
}

\author{
SYARIFAH $^{1,2, \bullet}$, ELFITA $^{3, v v}$, HARY WIDJAJANTI ${ }^{4}$, ARUM SETIAWAN $^{4}$, ALFIA R. KURNIAWATI ${ }^{2}$ \\ ${ }^{1}$ Graduate School of Sciences, Faculty of Mathematics and Natural Sciences, Universitas Sriwijaya. Jl. Padang Selasa, Palembang 30139, South Sumatra, \\ Indonesia."email: syarifah_uin@radenfatah.ac.id \\ ${ }^{2}$ Department of Biology, Faculty of Science and Technology, Universitas Islam Negeri Raden Fatah. J1. Prof. K.H. Zainal Fikri, Palembang 30126, South \\ Sumatra, Indonesia \\ ${ }^{3}$ Department of Chemistry, Faculty of Mathematics and Natural Sciences, Universitas Sriwijaya. J1. Raya Palembang Prabumulih Km. 32, Indralaya, \\ Ogan Ilir 30862, South Sumatra, Indonesia. Tel.: +62-711-580056, Fax.: +62-711-580268, "vemail: elfita.elfita.69@ gmail.com \\ ${ }^{4}$ Department of Biology, Faculty of Mathematics and Natural Sciences, Universitas Sriwijaya. Jl. Raya Palembang Prabumulih Km. 32, Indralaya, Ogan \\ Ilir 30862, South Sumatra, Indonesia
}

Manuscript received: 6 September 2021. Revision accepted: 28 September 2021.

\begin{abstract}
Syarifah, Elfita, Widjajanti H, Setiawan A, Kurniawati AR. 2021. Diversity of endophytic fungi from the root bark of Syzygium zeylanicum, and the antibacterial activity of fungal extracts, and secondary metabolite. Biodiversitas 22: 4572-4582. The decoction of the root bark of Syzygium zeylanicum has been used as traditional medicine, such as for treating pathogenic bacterial infections. Endophytic fungi that live in medicinal plant tissues have a high species diversity and biological activities correlate with their host. Therefore, this study aimed to explore the diversity of endophytic fungi from the root bark of S. zeylanicum and to determine the antibacterial activity of endophytic fungi and their secondary metabolites. In this study, we isolate and identify the endophytic fungi from the root bark of $S$. zeylanicum, continued by screening their antibacterial activity against two Gram-negative bacteria (Escherichia coli InaCCB5 and Salmonella thypi ATCC1048 and two Gram-positive bacteria (Staphylococcus aureus InaCCB4 and Bacillus subtilis InaCCB1204) by the Kirby-Bauer method. The fungal extract with the highest antibacterial activity proceeded with the isolation and determination of the structure of their bioactive compounds. The isolates were morphologically identified. Isolates that showed strong antibacterial activity were identified by molecular identification. Isolation of bioactive compounds was carried out by chromatographic techniques and the determination of the structure of pure chemical compounds was performed by the spectroscopic analysis. In total, there were 8 isolates of endophytic fungi were obtained from the root bark of S. zeylanicum, namely SZR1 - SZR8. SZR2 isolate has the highest antibacterial activity. Molecular identification through phylogenetic analysis showed that SZR2 isolate had high similarity with Penicillium brefeldianum. Isolation of bioactive compounds from SZR2 produced compound 1 in the form of light yellow crystals which showed strong antibacterial activity against $S$. typhi, E. coli, and B. subtilis with MIC values of $64 \mathrm{~g} / \mathrm{mL}$. Compound 1 was identified as phydroxybenzaldehyde, which was also obtained in its host. In conclusion, the endophytic fungus Penicillium brefeldianum produces similar secondary metabolites and antibacterial activity as its host plant.
\end{abstract}

Keywords: Antibacterial, bioactive compounds, endophytic fungi, Syzygium zeylanicum

\section{INTRODUCTION}

Endophytic fungi are microorganisms that live in healthy plant tissues and live in mutually beneficial relationships without causing plant diseases (Schueffler and Anke 2011). Endophytic fungi have great potential to acquire medically important new compounds. In addition, they also produce various compounds and interacts with other pathogenic and non-pathogenic microorganisms, thus playing a role in increasing productivity (Tayung et al. 2011; Arora and Ramawat 2017; Kothe and Turnau 2018). The efficacy of medicinal plants and their relationship with associated endophytic fungi has gained attention from scientists because of their pharmacological potential in synthesizing natural bioactive compounds (Chadwick and Marsh 2008). The Ogan ethnic-cultural group in South Sumatra has used parts of the Jambu nasi-nasi plant $(S$. zeylanicum) to treat various diseases. Leaves decoction is used to treat hypertension and diabetes (Nguyen et al. 2019), while its essential oil is used as a mosquito repellent
(Govindarajan and Benelli 2016). S. zeylanicum has been used by people in various parts of the world to treat infections caused by various pathogenic bacteria. This plant contains alkaloids, glycosides, phenolics, flavonoids, tannins, saponins, and steroids, with various biological activities, including as an antibacterial (Nomi et al. 2012; Anoop and Bindu 2015; Bhanu and Sabu 2017; Deepika et al. 2014; Mayasani et al. 2019). Plants that have been used as ethnomedicine for the treatment of certain diseases are promising candidates to obtain good bioactive compounds from their endophytic fungi (Uzma et al. 2019).

The development of antibiotic resistance by pathogenic bacteria poses a severe problem in the treatment of bacterial infections faced by healthcare services and has become a major concern worldwide. Therefore, the discovery of new antimicrobials is urgent. Endophytic fungi are a source of abundant species, which can produce secondary metabolites with high diversity ( $\mathrm{Li}$ et al. 2018; Ancheeva et al. 2020). However, the resources of endophytic fungi are still under-explored. In this study, we 
aimed to investigate the diversity of endophytic fungi from the root bark of $S$. zeylanicum, to obtain endophytic fungi with strong antibacterial activity, and to provide the basis for further research in obtaining novel antibiotic compounds. As far as we know, this is the first report on the diversity and antibacterial activity of endophytic fungi from the root bark of $S$. zeylanicum and its bioactive compounds.

\section{MATERIALS AND METHODS}

\section{Plant material}

The fresh root bark of Syzygium zeylanicum (Jambu nasi-nasi) was collected from District of Penukal Abab Lematang Ilir (PALI), South Sumatra, Indonesia. The plant has been identified in the Biosystematics Laboratory, Department of Biology, Sriwijaya University, Indonesia with specimen number 331/UN9.1.7/4/EP/2020. Sampling was carried out in February 2020. The root bark used in this study is root bark derived from roots in the soil.

\section{Isolation of endophytic fungi}

The fresh root bark was surface sterilized. It was washed with tap water until clean for \pm 5 minutes and then soaked using alcohol $70 \%$ for \pm 3 minutes, then rinsed with sterile distilled water for \pm 1 minute, and soaked with Sodium hypochlorite $(\mathrm{NaOCl}) 3 \%(\mathrm{w} / \mathrm{v})$ for 1 minute. The sterile root bark was cut aseptically, with the size of $\pm 3 \mathrm{x}$ $0.5 \mathrm{~cm}$. Samples were placed on potato dextrose agar (PDA) media in Petri dishes and incubated at room temperature for 3-14 days. Fungal growth was observed every day until the fungal colonies were visible. Fungal colonies with different morphological characters (shape, color, and size) were further purified. Purification was carried out by transferring the colonies to a new PDA medium with a single spore isolation method, then incubated at room temperature for 2 x 24 hours. The purified fungal colonies were re-cultured on PDA media as working culture (in Petri dishes) and stock cultures (in test tubes) (Fitriarni and Kasiamdari 2018; Hanin and Fitriasari 2019; Habisukan et al. 2021).

\section{Identification of endophytic fungi}

The identification of endophytic fungi was based on their macroscopic and microscopic characters. Observations of colony characteristics included: (i) colony color and reverse side color, (ii) colony surface: granular, powdery, mountainous, slippery. (iii) Presence or absence of exudate drops, (iv) Presence or absence of radial lines (radial furrow) from the center of the periphery of the colony, (v) presence or absence of concentric circles. Microscopic observations include the shape of the hyphae or mycelium, the shape of the spores, the color of the spores, the presence or absence of a septum on the hyphae, and other microscopic characteristics. The phenotypic identification data were compared to the identification key literature such as Pictorial Atlas of Soil and Seed Fungi Morphologies of Cultured Fungi and Key to Species (Watanabe 2010), Larone's medically important fungi
(Walsh et al. 2018), and Fungi and Food Spoilage (Pitt and Hocking 2009).

\section{Cultivation and extraction}

All endophytic fungal strains were cultivated by placing 6 blocks of pure culture grown on PDA $( \pm 6 \mathrm{~mm}$ in diameter) into a $300 \mathrm{~mL}$ Potato Dextrose Broth (PDB) medium. Each isolate was cultivated in 5 Erlenmeyer with a volume of $300 \mathrm{~mL}$ PDB. The culture was then incubated under static conditions at room temperature for 4 weeks. After incubation, mycelium and broth culture were separated using filter paper. The culture medium was extracted using ethyl acetate (1:1) three times. The ethyl acetate extract was separated from the culture medium by separating funnel and evaporated using a rotary evaporator (Deepika et al. 2014; Habisukan et al. 2021). The extract was concentrated using an oven at $40^{\circ} \mathrm{C}$. The concentrated extract and biomass were weighed using an analytical balance.

\section{Antibacterial activity test}

The antibacterial activity was carried out by the KirbyBauer method using NA (Nutrient Agar) medium against four bacterial isolates, namely two Gram-negative bacteria (Escherichia coli InaCCB5 and Salmonella thypi ATCC1048 and two Gram-positive bacteria (Staphylococcus aureus InaCCB4 and Bacillus subtilis InaCCB1204). The endophytic fungal extract was dissolved with dimethylsulfoxide (DMSO). The blank disc paper was dripped with $20 \mu \mathrm{L}$ of an endophytic fungal extract with a concentration of $400 \mu \mathrm{g} / \mathrm{disk}$, then left until all the solvent evaporates completely. Positive control was Tetracycline $30 \mu \mathrm{g} / \mathrm{disk}$. The disc paper with the test solution was placed on the NA medium that has been inoculated with the test bacteria. Then it is incubated for $1 \times 24$ hours at a temperature of $37^{\circ} \mathrm{C}$. After incubation, the inhibition zone was observed using a caliper to measure the inhibitory zone diameter. The measurement of the antibacterial activity of the sample and the criteria for the diameter of the inhibition zones were determined by the following equation (Elfita et al. 2019) :

$$
\begin{aligned}
& \text { Weak: } \frac{\mathrm{A}}{\mathrm{B}} \mathrm{x} 100 \%<50 \% \\
& \text { Middle: } 50 \%<\frac{\mathrm{A}}{\mathrm{B}} \mathrm{x} 100 \%<70 \% \\
& \text { Strong: } \frac{\mathrm{A}}{\mathrm{B}} \mathrm{x} 100 \%>70 \% \\
& \text { Where: } \\
& \text { A: Inhibition zone }(\mathrm{mm}) \text { of the test sample } \\
& \text { B: Inhibition zone }(\mathrm{mm}) \text { of standard antibiotics }
\end{aligned}
$$

Determination of the MIC of the pure compound isolated from SZR2 was carried out in the concentration range of $256-1 \mathrm{~g} / \mathrm{mL}$. Positive antibacterial was determined by the diameter of inhibition zone $>9 \mathrm{~mm}$ at a certain concentration series. The lowest concentration in the bacterial positive series is defined as the MIC value (Ding et al. 2019). 


\section{Molecular analysis of ITS rDNA}

Identification of isolates based on the internal transcribed spacer (ITS) region of DNA (rDNA). Amplification was carried out using universal primers ITS1 (5'-TCCGTAGGTGAACCTGCGG-3') and ITS 4 (5'TCCTCCGCTTATTGATATGC-3') (Diongue et al. 2019). The DNA sequences of the forward and reverse primers were compiled using the Bioedit program. The sequence results were then identified to the level of taxa species using the online bioinformatics method of the Basic Local Alignment Search Tool (BLAST) at the website address http://blast.ncbi.nlm.nih.gov/Blast.cgi. Subsequently, multiple alignments were performed using the Mega 6 program (Tamura et al. 2013) use the CLUSTAL W method and the phylogenetic tree was constructed using the Neighbor-joining tree method with a bootstrap value of 1000 (Katoch and Pull 2017; Kuswytasari et al. 2019; Potshangbam et al. 2017).

\section{Bioactive compound isolation and identification}

The crude extract with strong antibacterial activity was separated using column chromatography (stationary phase: silica gel) and eluted with gradient elution (n-hexane: ethyl acetate: methanol). Eluates were collected in vials with a volume of $10 \mathrm{ml}$ and monitored by TLC analysis to obtain subfractions. The subfraction identified as having active secondary metabolites was then purified by column chromatography until pure compounds were obtained. The structures of the compounds were identified by spectroscopic methods include ${ }^{1} \mathrm{H}-\mathrm{NMR},{ }^{13} \mathrm{C}-\mathrm{NMR}$, HMQC, HMBC (Budiono et al. 2019).

\section{RESULTS AND DISCUSSION}

The purpose of the isolation of fungal endophytes from S. zeylanicum is to identify and investigate the fungal diversity associated with the root bark. The appearance of hyphae that emerged around surface-sterilized plant tissue indicates the growth of endophytic fungal isolates. Colonies of endophytic fungal isolates have different morphological characters. Massive hyphae growth emerged from the root bark samples, mainly white colonies and yellow pigmentation. Isolation of endophytic fungi from the Jambu nasi-nasi root bark results in 8 isolates with codes SZR1 to SZR8 (Figure 1) which have different morphological characteristics (shape, color, and size). Endophytic fungi from root bark showed colony diversity in terms of colony size, color (white, black, green, and gray), and texture (velvet, cotton, and powdery).

\section{Endophytic fungi morphological identification}

Endophytic fungi that have been isolated from $S$. zeylanicum were identified based on their morphological characters, both macroscopically and microscopically (Kumar et al. 2019). The morphology of endophytic fungi is presented in Figure 2. Macroscopic and microscopic characteristics were presented in Table 1 and Table 2, respectively.

SZR1 isolate had a velvety colony texture with a yellowish-white color; the key species of this isolate was a non-verticillate phialide with dangling subglobose conidia so that the SZR1 isolate was close to Paecilomyces victorae (Watanabe 2010). SZR2 has almost the same colonies as SZR1 isolates with greenish-white colonies, conidiophores form was monoverticillate penicillin consisting of several phialides, metulae, and catenulate conidia at the apex: pointed phialides pens with abruptly pointed ends. The characteristics of SZR2 based on the book Watanabe (2010) are close to the genus Penicillium. Molecular analysis of SZR2 suggests that SZR2 was close to Penicillium brefeldianum.

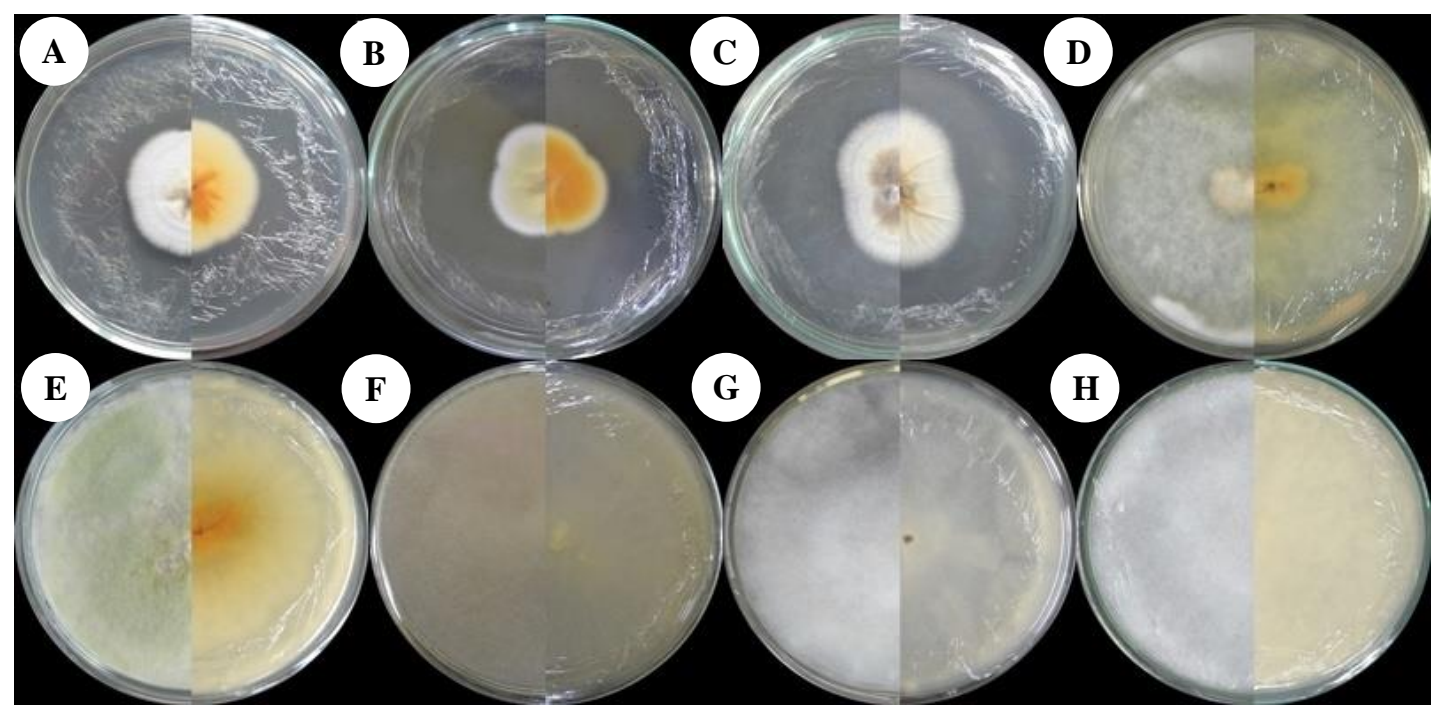

Figure 1. Endophytic fungi from the root bark of Syzygium zeylanicum. Isolate code: A. SZR1; B. SZR2; C. SZR3; D. SZR4; E. SZR5; F. SZR6; G. SZR7; and H. SZR8 


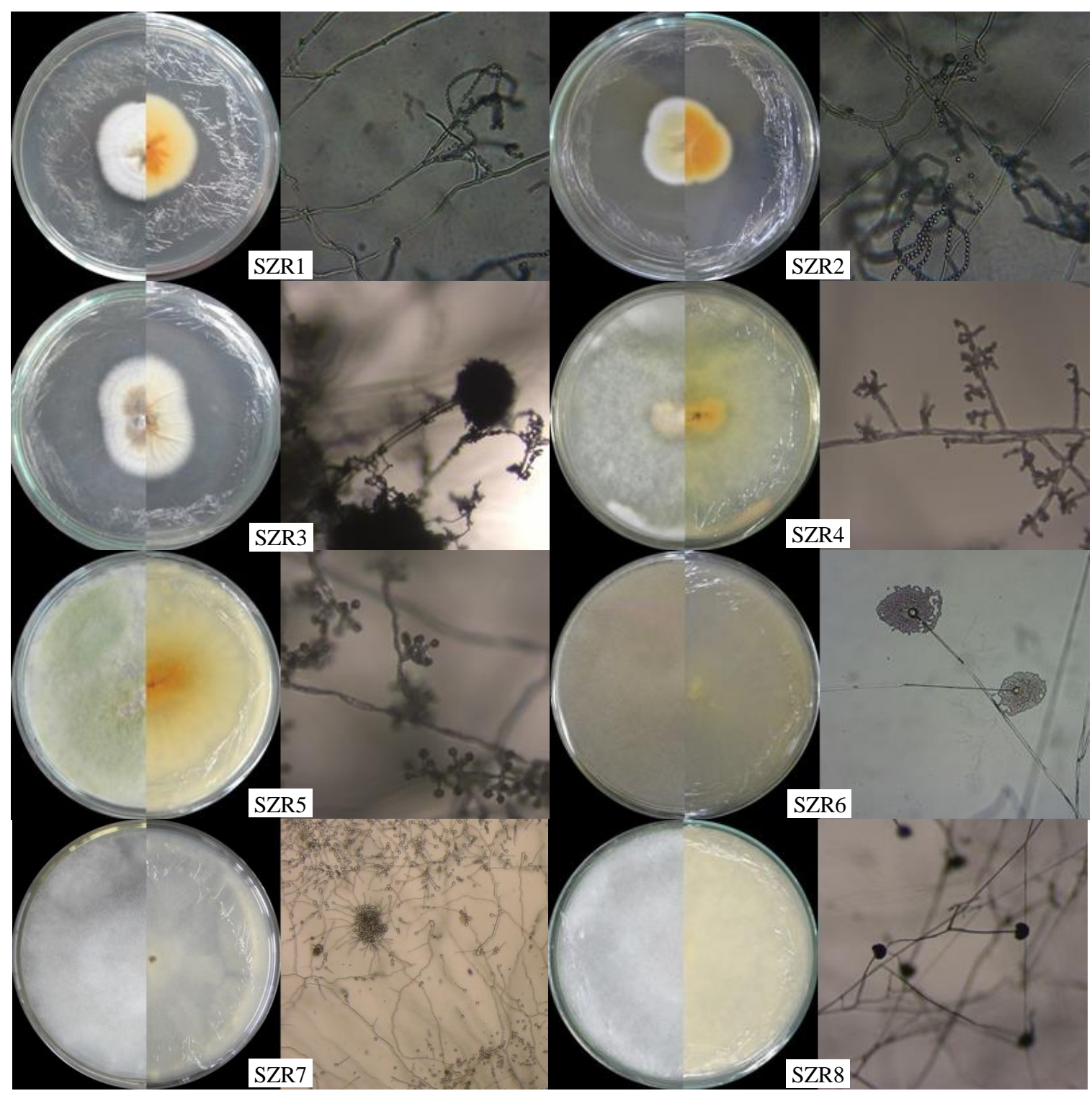

Figure 2. Morphology of endophytic fungi from the root bark of Syzygium zeylanicum (macroscopic and microscopic characters)

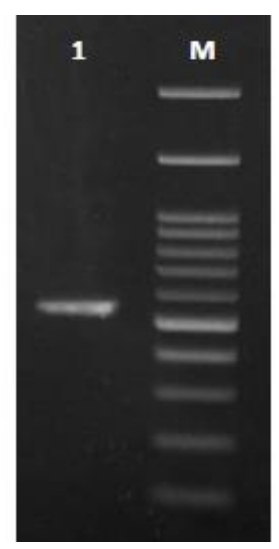

$$
\begin{gathered}
1 \mu \mathrm{L} \text { PCR } \\
\text { Products were } \\
\text { assessed by } \\
\text { electrophoresis } \\
\text { with } 1 \% \text { TBE } \\
\text { agarose } \\
\\
\mathrm{M}, 100 \text { bp DNA } \\
\text { ladder (loaded } \\
2,5 \mu \mathrm{L} \text { ); samples } \\
\text { ranged in the } \\
\text { order of upper } \\
\text { table }
\end{gathered}
$$

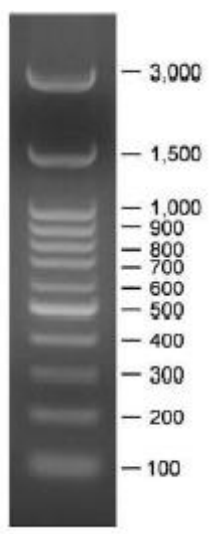

Figure 3. Electrophoresis results of ITS rDNA sequences of endophytic fungus SZR2 
Table 1. Colony characteristics of endophytic fungi from the root bark of Syzygium zeylanicum

\begin{tabular}{|c|c|c|c|c|c|c|c|c|}
\hline Code & Surface colony & Reverse colony & Structure & Elevation & Pattern & $\begin{array}{c}\text { Exudate } \\
\text { drops }\end{array}$ & $\begin{array}{c}\text { Radial } \\
\text { line }\end{array}$ & $\begin{array}{c}\text { Concentric } \\
\text { circle }\end{array}$ \\
\hline SZR1 & Greenish white & Yellowish white & Velvety & Rugose & Zonate & - & - & $\sqrt{ }$ \\
\hline SZR2 & Yellowish green & Light yellow & Velvety & Rugose & Zonate & - & - & $\sqrt{ }$ \\
\hline SZR3 & Black and White around & Broken White & Powdery & Rugose & Zonate & - & $\sqrt{ }$ & - \\
\hline SZR4 & Greenish-yellow & Light yellow & Cottony & Raised & Spread & - & - & - \\
\hline SZR5 & Greenish-yellow & Yellowish white & Cottony & Raised & Spread & - & - & - \\
\hline SZR6 & Gray & Gray & Cottony & Raised & Spread & $\sqrt{ }$ & - & - \\
\hline SZR7 & White & White & Cottony & Umbonate & Spread & - & - & $\sqrt{ }$ \\
\hline SZR8 & Milky white & Yellowish white & Cottony & Umbonate & Spread & - & - & $\sqrt{ }$ \\
\hline
\end{tabular}

Note: (-): present; $(\sqrt{ })$ : absent

Table 2. Microscopic characteristics of Syzygium zeylanicum endophytic fungi

\begin{tabular}{|c|c|c|c|c|c|}
\hline Isolate & Spore & Shape & Hyphae & Characteristic & Species of Identification \\
\hline SZR1 & Conidia & Verticillate & Septate & Hyaline conidiophyte, verticillate & Paecilomyces victorae \\
\hline SZR2 & Conidia & Globose & Septate & Bearing monoverticillate penicilla & Penicillium brefeldianum \\
\hline SZR3 & Conidia & Globose & Septate & Globose vesicle, conidia black in mass & Aspergillus niger \\
\hline SZR4 & Conidia & Subglobose & Septate & Spore masses apically, conidia globose & Trichoderma harzianum \\
\hline SZR5 & Conidia & Subglobose & Septate & Ovate conidia, short phialides, densely arranged & Trichoderma aureoviridae \\
\hline SZR6 & Sporangiospore & Globose & Coenocytic & $\begin{array}{l}\text { Sporangiophores erect, branched, rhizoidal } \\
\text { basally; vesicles hyaline globose. }\end{array}$ & Syncephalastrum racemosum \\
\hline SZR7 & Ascospore & Subglobose & Septate & Ascocarps with well-developed hair & Chaetomium sp. \\
\hline SZR8 & Sporangiospore & Globose & Coenocytic & $\begin{array}{l}\text { Sporangiophores hyaline, erect. Sporangia dark; } \\
\text { columellae hemispherical subglobose }\end{array}$ & Absidia repens \\
\hline
\end{tabular}

The isolate of SZR3 had the characteristics of a powdery texture with black colonies in the middle and white at the edges. SZR3 has septate hyphae, hyaline conidiophores with spherical vesicles surrounded by masses of black conidia, characteristic of this isolate leading to Aspergillus niger (Walsh et al. 2018).

SZR4 and SZR5 isolates have almost the same colonies with cotton texture and whitish green color (Figure 2). Both isolates had branching conidiophores, with a mass of spores in each phialide, SZR5 had oval conidia, short, thick, tightly arranged conidia so that they were close to Trichoderma aureoviride, while the conidia in isolate SZR4 were globose so this isolate is close to Trichoderma harzianum (Watanabe 2010). SZR6 has a cottony texture and spreads quickly gray. SZR6 has erect, branched, rhizoid sporangiophores at the base; a globose hyaline vesicle. Based on these characters, SZR6 is close to the Syncephalastrum racemosum (Walsh et al. 2018; Watanabe 2010).

SZR7 and SZR8 had white colonies with cotton texture but different colors of the reverse side where SZR8 had darker yellow color (Figure 2). Microscopically the two isolates had different characteristics. The ascocarps of SZR7 have elongated hairs around the ascocarps. The characteristics of SZR7 lead to Chaetomium sp. (Watanabe 2010). Meanwhile, SZR8 has hyaline sporangiophores, erect, dark sporangia with the subglobose hemispherical columella. These characteristics of SZR8 point to the species of Absidia repens (Watanabe 2010; Hoffmann et al. 2007).
Based on the morphological characteristics, the isolates from the root bark of $S$. zeylanicum were grouped into three classes, i.e., Euriomycetes (SZR1, SZR2, and SZR3), Sordariomycetes (SZR4, SZR5, and SZR7), and Zygomycetes (SZR 6 and SZR8). Endophytic fungi isolated from the root bark of $S$. zeylanicum showed a variety of spore forms (verticillate, globose, and subglobose) (Table 2). Most of the isolates had septate hyphae, except isolates SZR6 and SZR8 which had coenocytic hyphae.

\section{Molecular analysis of ITS rDNA}

Molecular characterization combined with morphological identification can identify fungus to the species level (Gherbawy and Voigt 2010). Molecular characterization was carried out on the Internal Transcribed Spacer (ITS) rDNA area. Currently, there are more than 90,000 fungal sequences in the ITS area, where this area is most widely used as a barcode area for fungi (Hibbett et al. 2011; Singh et al. 2020). PCR analysis used a pair of universal primers, namely ITS1 for the forward primers and ITS4 for the reverse primers. The amplification results of the ITS rDNA area varied by $\pm 500 \mathrm{bp}$ (Figure 3 ). Sequence reading results from each of the forward and reverse primers were processed by cutting the ends of the sequences with low peaks using the Bioedit program. Furthermore, the sequences are aligned so that the compilation sequences of the forward and reverse primers from the ITS rDNA area are obtained.

Sequences from the ITS rDNA area of the SZR2 isolate were analyzed for intraspecies similarity with the data in 
Genbank NCBI using the BLAST algorithm. The relationship between sequences can be observed through the construction of a phylogenetic tree using the distance calculation method, namely the neighbor-joining phylogenetic tree. The purpose of using this method is to determine the position of the isolate sequence to the closest sequence (sequences that have a small base pair difference) so that the distance between each sequence can be seen (Ahrenfeldt et al. 2017). Sequence collections were aligned using CLUSTAL $\mathrm{W}$ in the MEGA6 program, and a phylogenetic tree was constructed (Figure 4).

The results of the construction of the SZR2 endophytic fungal phylogeny tree are shown in Figure 4. The SZR2 phylogenetic tree shows that the isolate sequence is close to Penicillium vanderhemmenii, Penicillium Penarojense, and is in the same branch as Penicillium brefeldianum. The phylogenetic analysis indicated that the SZR2 isolate was included in the taxonomy of $P$. brefeldianum, this was following the phenotypic character previously discussed.

\section{Cultivation and extraction}

The weight of endophytic fungal extracts are as follows: $\mathrm{SZR} 1=5.9 \mathrm{~g}, \mathrm{SZR} 2=6.2 \mathrm{~g}, \mathrm{SZR} 3=5.5 \mathrm{~g}, \mathrm{SZR} 4=5.7 \mathrm{~g}$, SZR5 = $5.1 \mathrm{~g}, \mathrm{SZR} 6=4.7 \mathrm{~g}, \mathrm{SZR} 7=5.3 \mathrm{~g}$, and $\mathrm{SZR} 8=5.8 \mathrm{~g}$.

\section{Antibacterial activity test}

The antibacterial activity of the ethyl acetate extract of the endophytic fungi from the root bark of S. zeylanicum is shown in Table 4. The isolate that had strong antibacterial activity against four microbial pathogens was SZR2 isolate, while SZR1 and SZR4 had strong antibacterial against 3 pathogenic bacteria and moderate antibacterial activity against B. subtilis. SZR6 and SZR8 showed weak antibacterial activity against $B$. subtilis and moderate antibacterial activity against the other three bacterial pathogens.

\section{Isolation of bioactive compound}

The eluate from column chromatography was monitored using thin-layer chromatography (TLC) with a mobile phase of n-hexane and ethyl acetate (5:5). TLC profile with a similar chromatogram pattern was combined into one fraction. Based on the results of the chromatogram pattern, 4 fractions were obtained, namely F1-F4. White crystals were formed in the F2 fraction, and after being purified with n-hexane, compound 1 was obtained in the form of white crystals weighing $37 \mathrm{mg}$. Compound1 showed good antibacterial activity against E. coli, S. typhi, and B. subtilis with a MIC value of $64 \mathrm{~g} / \mathrm{mL}$ (Table 2).

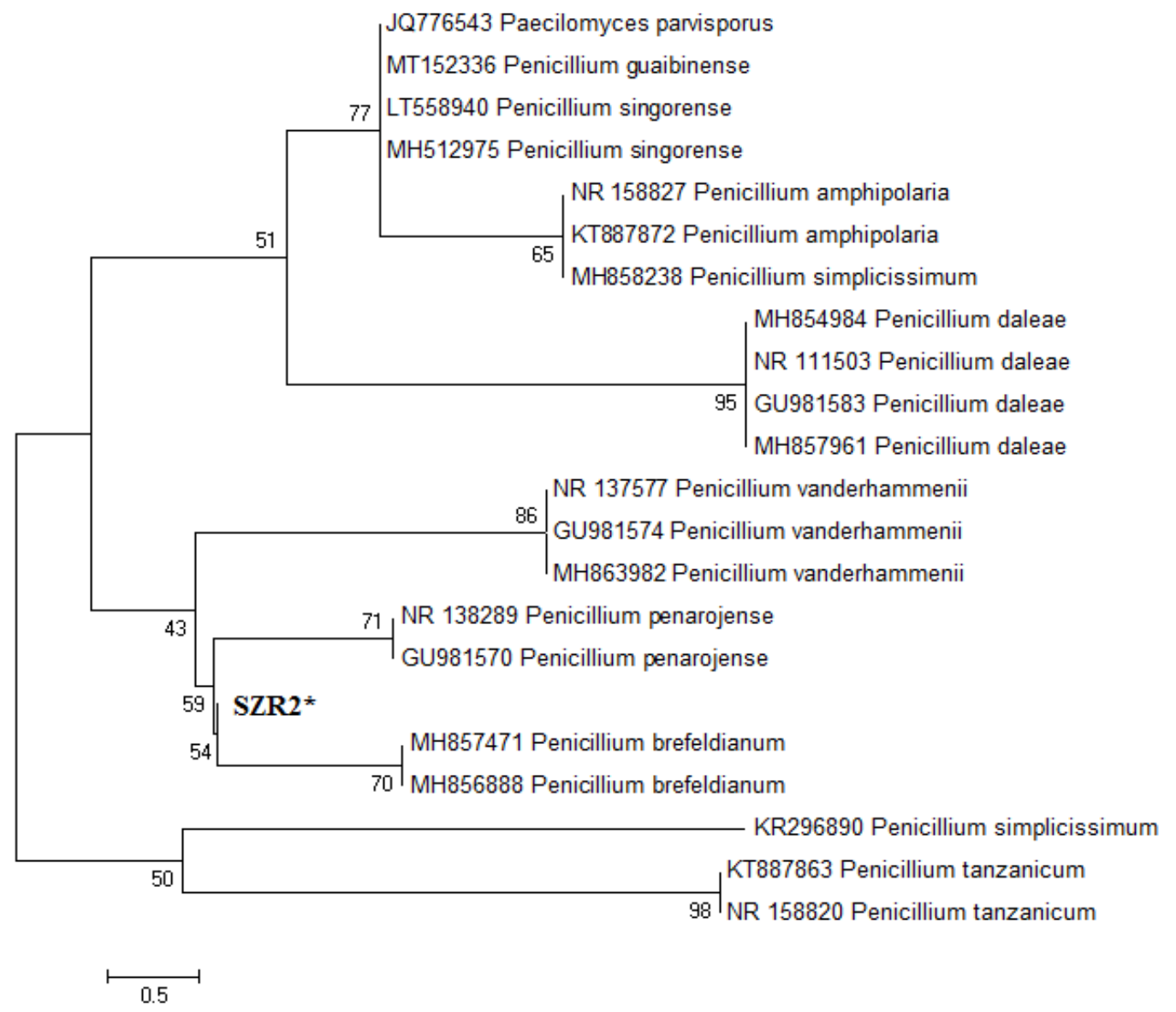

Figure 4. Phylogenetic tree of endophytic fungus SZR2. The construction uses the Neighbor-Joining method. The endophytic fungi SZR2 indicated by an asterisk [*] were subject to phylogenetic analysis with related species using a neighbor-joining phylogenetic tree (bootstrap value $=1000$ ). Sequences obtained from the BLAST results. The value on the branch shows the bootstrap value (percentage of $1000 \mathrm{x}$ replications) 
Table 3. Antibacterial activity of ethyl acetate extract of endophytic fungi from S. zeylanicum (SZR1-SZR8) compared to standard antibiotics (tetracyclines)

\begin{tabular}{|c|c|c|c|c|}
\hline \multirow[t]{2}{*}{ Sample $(400 \mu \mathrm{g} / \mathrm{disc})$} & \multicolumn{4}{|c|}{$\begin{array}{l}\text { Comparison of the inhibition zone }(\mathrm{mm}) \text { of the sample to the inhibition zone of tetracycline } \\
\text { antibiotics }(\mathrm{mm}) \text { expressed in \% antibacterial activity a }\end{array}$} \\
\hline & E. coli & S. aureus & S. thypi & B. subtilis \\
\hline SZR1 & $\begin{array}{l}14.3 \pm 0.6 \\
73.4 * * *\end{array}$ & $\begin{array}{l}16.3 \pm 1.6 \\
79.7 * * *\end{array}$ & $\begin{array}{l}15.3 \pm 1.8 \\
73.0^{* * * *}\end{array}$ & $\begin{array}{l}16.1 \pm 0.8 \\
67.5 * *\end{array}$ \\
\hline SZR2 & $\begin{array}{l}15.8 \pm 1.5 \\
80.7 * * *\end{array}$ & $\begin{array}{l}16.4 \pm 0.7 \\
80.2 * * *\end{array}$ & $\begin{array}{l}18.3 \pm 0.8 \\
87.2^{* * * *}\end{array}$ & $\begin{array}{l}20.5 \pm 0.5 \\
86.1 * * *\end{array}$ \\
\hline SZR3 & $\begin{array}{l}12.9 \pm 0.4 \\
65.9 * *\end{array}$ & $\begin{array}{l}14.0 \pm 0.6 \\
68.5 * *\end{array}$ & $\begin{array}{l}15.3 \pm 1.5 \\
72.8 * * *\end{array}$ & $\begin{array}{l}13.4 \pm 1.2 \\
56.5 * *\end{array}$ \\
\hline SZR4 & $\begin{array}{l}15.4 \pm 0.8 \\
78.7 * * *\end{array}$ & $\begin{array}{l}17.0 \pm 1.5 \\
82.8 * * *\end{array}$ & $\begin{array}{l}14.8 \pm 1.7 \\
70.6 * * *\end{array}$ & $\begin{array}{l}16.1 \pm 1.5 \\
67.9 * *\end{array}$ \\
\hline SZR5 & $\begin{array}{l}13.5 \pm 1.1 \\
68.8 * *\end{array}$ & $\begin{array}{l}13.7 \pm 0.5 \\
66.8 * *\end{array}$ & $\begin{array}{l}15.0 \pm 1.0 \\
71.4 * * *\end{array}$ & $\begin{array}{l}14.8 \pm 1.6 \\
62.2 * *\end{array}$ \\
\hline SZR6 & $\begin{array}{l}11.6 \pm 1.7 \\
59.3 * *\end{array}$ & $\begin{array}{l}11.2 \pm 1.0 \\
54.5 * *\end{array}$ & $\begin{array}{l}10.2 \pm 1.9 \\
48.5 *\end{array}$ & $\begin{array}{l}9.4 \pm 1.4 \\
39.5 *\end{array}$ \\
\hline SZR7 & $\begin{array}{l}14.6 \pm 1.1 \\
74.6 * * *\end{array}$ & $\begin{array}{l}12.6 \pm 1.2 \\
61.7 * *\end{array}$ & $\begin{array}{l}15.4 \pm 0.7 \\
73.2 * * *\end{array}$ & $\begin{array}{l}13.7 \pm 1.5 \\
57.8^{* *}\end{array}$ \\
\hline SZR8 & $\begin{array}{l}12.3 \pm 1.3 \\
63.2 * *\end{array}$ & $\begin{array}{l}10.9 \pm 0.3 \\
53.4 * *\end{array}$ & $\begin{array}{l}14.3 \pm 1.5 \\
68.1 * *\end{array}$ & $\begin{array}{l}10.0 \pm 0.8 \\
42.2 *\end{array}$ \\
\hline Tetracycline & $\begin{array}{l}19.5 \pm 1.4 \\
100 * * *\end{array}$ & $\begin{array}{l}20.5 \pm 1.7 \\
100 * * *\end{array}$ & $\begin{array}{l}21.0 \pm 1.0 \\
100 * * *\end{array}$ & $\begin{array}{l}23.8 \pm 1.2 \\
100 * * *\end{array}$ \\
\hline
\end{tabular}

Note: ${ }^{a}: * * *$ Strong inhibition $\geq 70 \% \quad * *$ middle inhibition 50-70\% $\quad *$ weak inhibition < 50\% (NI) No Inhibition zone

Table 4. MIC value of pure compound 1 and tetracycline against four bacterial isolates

\begin{tabular}{lcccc}
\hline \multirow{2}{*}{ Sampel } & \multicolumn{3}{c}{ MIC Value $(\boldsymbol{\mu g} / \mathbf{m L})$} \\
\cline { 2 - 5 } & E. coli & S. aureus & S. thypi & 64 \\
Compound 1 & 64 & 128 & 64 & 64 \\
Tetracycline & 1 & 1 & 1 & 1 \\
\hline
\end{tabular}

Note: Zone of Inhibition $>9 \mathrm{~mm}$ indicates that the compound has antibacterial activity at the appropriate concentrations

\section{Determination of chemical structure}

The spectrum of $1 \mathrm{H}-\mathrm{NMR}$ of the pure compound 1 showed the presence of three protons signals including two doublet signals at H 6.95 and 7.80 ppm, each of which had two proton integrations. These two signals are in the chemical shift of the aromatic region and each has an ortho-lot constant $(\mathrm{J}=8 \mathrm{~Hz})$ which indicates that the pure compound is an aromatic compound with para position substitution. This causes two pairs of ortho protons to appear in the same chemical shift. In addition, there is a signal in the low field of $9.85 \mathrm{ppm} \mathrm{H}$, namely in the proton aldehyde region. Based on the analysis of the $1 \mathrm{H}-\mathrm{NMR}$ spectrum, the pure compound is a para-substituted aromatic compound with a total of five protons.

The spectrum of 13C-NMR from pure compound 1 showed the presence of five signals. The carbon type in the spectrum can be seen from the chemical shift and its intensity. All the carbon possessed by a pure compound is sp2. Carbon at C 116.0 and 132.5 ppm with high intensity indicate that there are 2 carbon equivalents in each of these signals. This is supported by the $1 \mathrm{H}-\mathrm{NMR}$ spectrum which shows the presence of two equivalent protons. In the spectrum, there is carbon in the low field of C $191.0 \mathrm{ppm}$, namely the carbonyl carbon region. This high-intensity pattern on the carbonyl carbon indicates that the pure compound has an aldehyde group. This is supported by the presence of an aldehyde proton signal in the 1H-NMR spectrum. Signals at C 130.2 and 161.2 ppm are quaternary aromatic carbon, where carbon at $161.2 \mathrm{ppm}$ is oxyaryl carbon so it is in a fairly low field. The analysis of the proton and carbon NMR spectra is reinforced by the data on the HSQC spectrum shown in Table 1 which shows that there are three $1 \mathrm{H}-13 \mathrm{C}$ correlations through one bond consisting of two correlations on the aromatic ring and one correlation on the carbonyl carbon.

The HMBC spectrum (Figure 6) shows the $1 \mathrm{H}-13 \mathrm{C}$ correlation through two or three bonds. The aromatic proton signal at $\mathrm{H} 6.95 \mathrm{ppm}$ is correlated through three bonds with its equivalent aromatic carbon ( $\delta \mathrm{C} 116.0 \mathrm{ppm})$; quaternary aromatic carbon $(\delta \mathrm{C} 130.2 \mathrm{ppm})$; and oxyaryl quaternary carbon $(\delta \mathrm{C} 161.2 \mathrm{ppm})$. The aromatic proton at $\mathrm{H} 7.80 \mathrm{ppm}$ is correlated through three bonds with its equivalent aromatic carbon ( $\delta \mathrm{C} 132.5 \mathrm{ppm}$ ); oxyaryl quaternary carbon ( $\delta \mathrm{C} 161.2 \mathrm{ppm})$; and carbonyl aldehyde carbon ( $\delta \mathrm{C} 191.0 \mathrm{ppm})$. Furthermore, the aldehyde proton is correlated through three bonds with the equivalent aromatic carbon at C $132.5 \mathrm{ppm}$. The correlation indicates that the aldehyde group is directly attached to the aromatic ring and is para-substituted with a hydroxyl group. The proton hydroxyl signal does not appear on the spectrum because the pure compound is measured with the solvent $\mathrm{CDCl} 3$. The $2 \mathrm{D}$ and1D NMR spectral data for compound 1 
are shown in Table 5.

Based on spectroscopic analysis covering the 1H-NMR spectrum, 13C-NMR, HMQC, and HMBC, and by comparing with the spectroscopic data for the same compound from the literature, it was identified that compound 1 was 4-hydroxybenzaldehyde or phydroxybenzaldehyde. Compound 1 structure is shown in Figure 7.

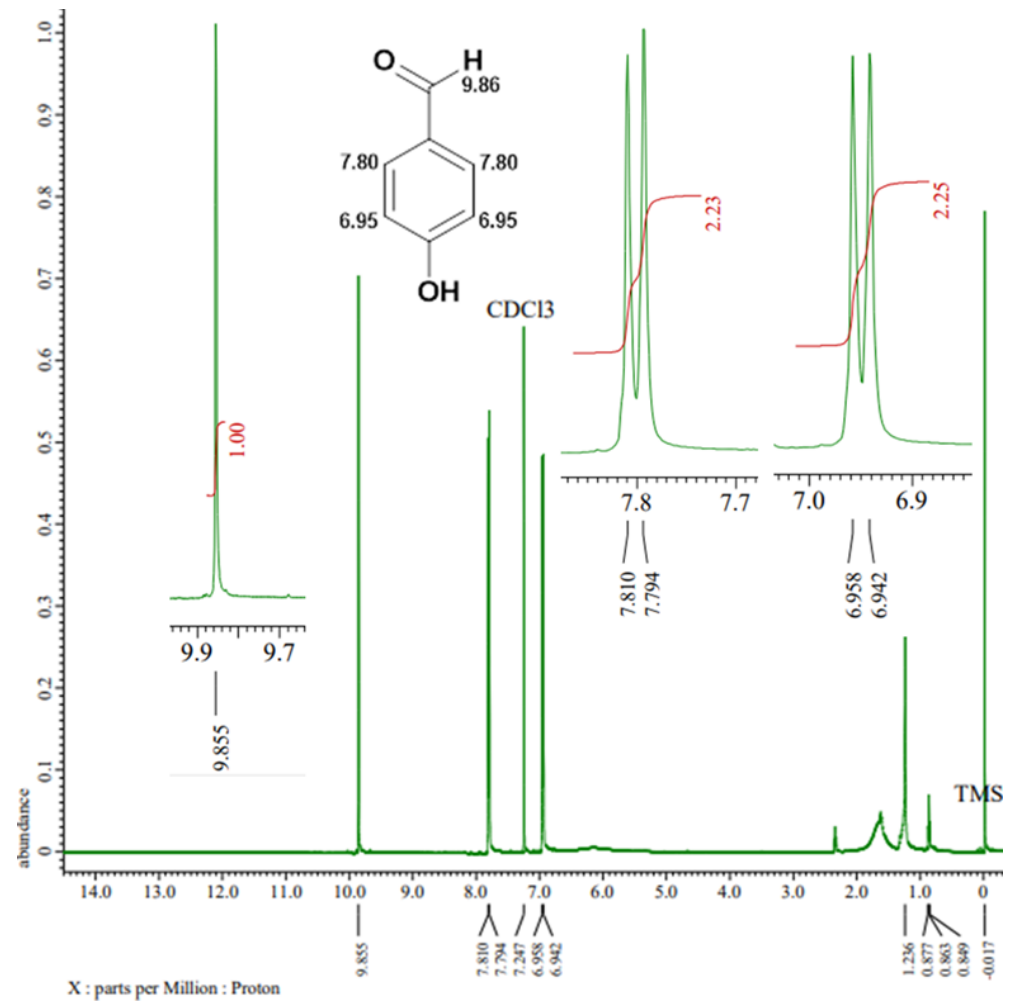

Figure 5. The spectrum of 1H-NMR of compound 1

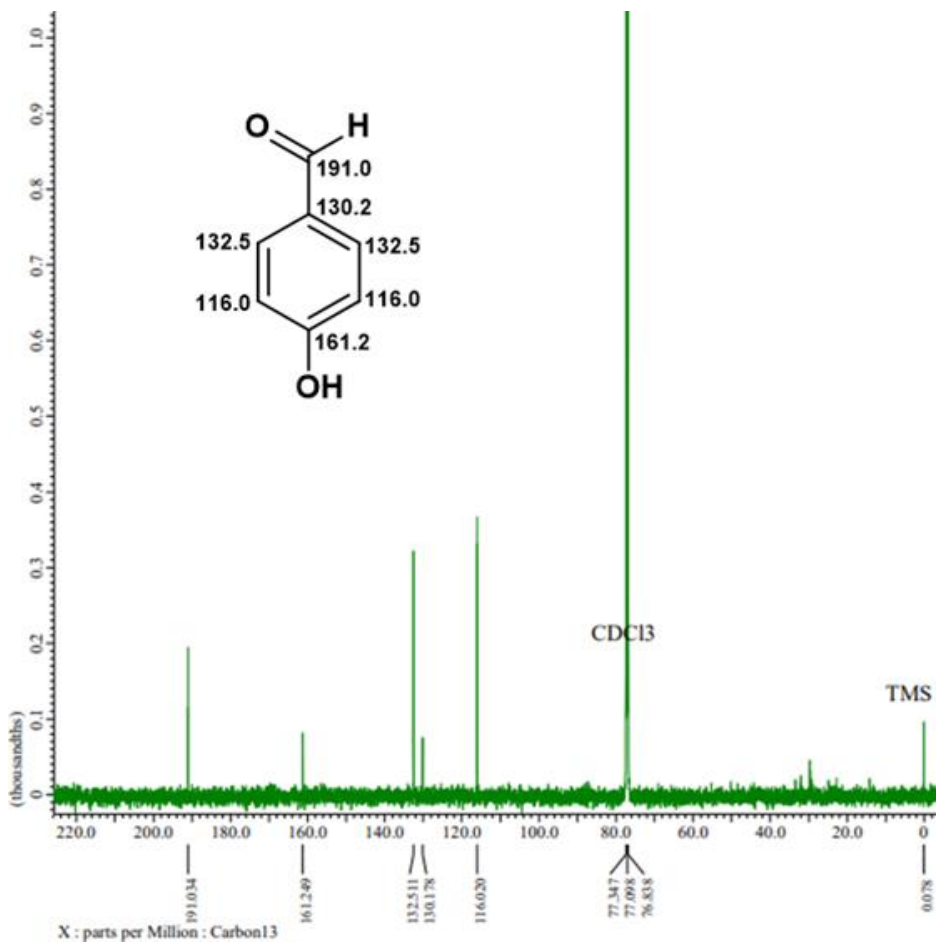

Figure 6. ${ }^{13} \mathrm{C}-\mathrm{NMR}$ spectrum of compound 1 


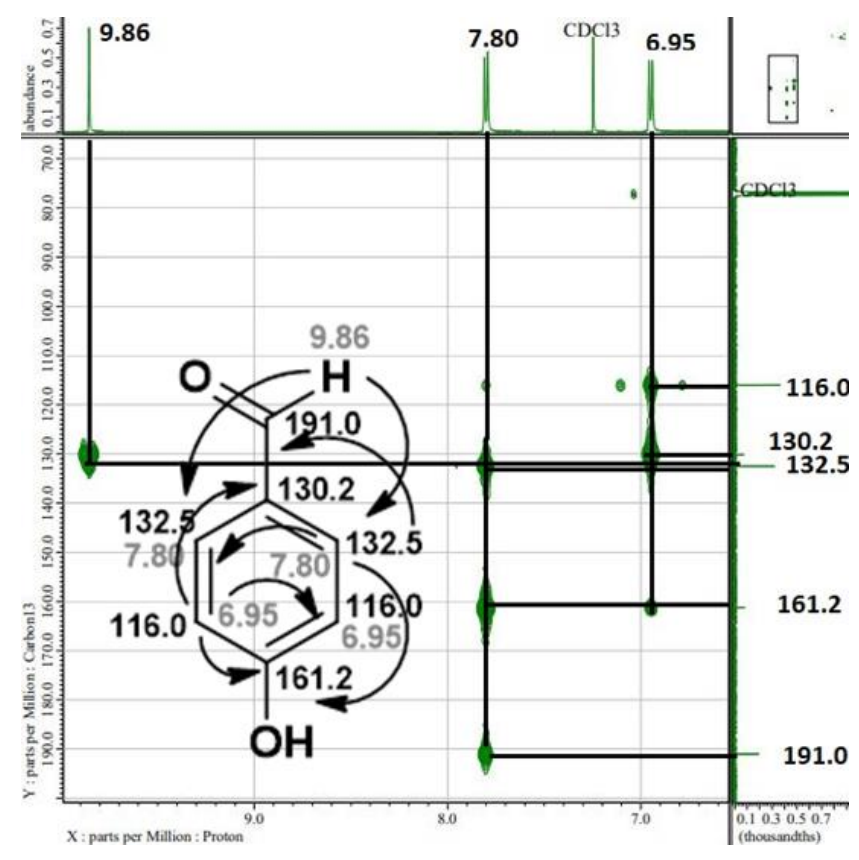

Figure 7. HMBC spectrum of compound 1

\section{Discussion}

The isolation process was carried out on a PDA medium because fungal cultures grew faster on this medium and several species might not have been isolated before. The diversity of endophytic fungi isolates was not only found in $S$. zeylanicum but was also found in the isolation of endophytic fungi from S. cumini (Hanin and Fitriasari 2019), S. aqeueum (Habisukan et al. 2021), $S$. aromaticum (Shofiana et al. 2015).

Several genera of fungi isolated from the root bark of $S$. zeylanicum were found on other Syzygium plants, such as the genus Penicillium found on the leaves of Syzygium aqueum (Habisukan et al. 2021). The genus Aspergillus is found in Syzygium aqueum (Habisukan et al. 2021), Syzygium aromaticum (Shofiana et al. 2015), and Syzygium paniculatum (Ploetz et al. 2009). Penicillium brefeldianum has cytotoxic activity against HepG2 and MDA-MB-231 cells, this fungus had been isolated from the root of Pinellia ternate (Gao et al. 2017). The endophytic fungus Aspergillus has a wide range of biological activities because it produces many secondary metabolites, including alkaloids, butenolides, cytochalasins, terpenoids, terphenyls, phenalenone, sterols, xanthones, diphenyl ethers, and anthraquinone derivatives. The biological activities of Aspergillus include anticancer, antifungal, antibacterial, antiviral, antiinflammatory, antitrypanosomal, and antileishmanial activities (El-Hawary et al. 2020).

The endophytic fungi of Trichoderma species (SZR4 and SZR5 isolates) that are associated with plant roots can provide various benefits to their hosts such as cultural protection agents to control pathogens and promote plant growth (Cummings et al. 2016) The root-associated Trichoderma endophytes have been found in several tropical plants (Cummings et al. 2016) such as Syzygium aqueum (Habisukan et al. 2021), Syzygium aromaticum (Mandla 2018). The endophytic fungus SZR7 identified as Chaetomium was also found in Syzygium aqueum (Habisukan et al. 2021). Chaetomium is also an endophytic fungus from Curcuma wenyujin and produces chemical compounds such as chaetoglobosin, ergosterol, 2-methyl-3hydroxy indole, and chaetoglobosin X. Those compounds exhibit a broader antifungal spectrum and showed the strongest cytotoxic activity against $\mathrm{H} 22$ and MFC cancer cell lines (Wang et al. 2012). SZR8 isolate that identified as Absidia was found in several plants, such as Phragmites australis, Galium sanaicum, Meyna spinosa, Avicennia officinalis (Rashmi et al. 2019), however, the discovery of Absidia in the genus Syzygium in this study was the first report.

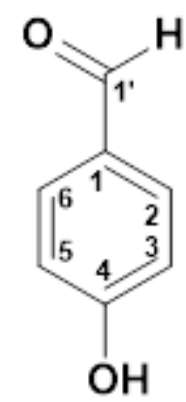

Figure 7. The structure of compound 1 as phydroxybenzaldehyde

Table 5. 1D and 2D NMR Spectral Data for Compound 1

\begin{tabular}{|c|c|c|c|c|}
\hline No. $\mathrm{C}$ & $\begin{array}{c}\boldsymbol{\delta}_{\mathrm{C}}(\mathbf{p p m}) \\
\mathbf{1}\end{array}$ & $\begin{array}{c}\text { H-NMR } \\
\delta_{\mathrm{H}}(\mathrm{ppm})^{*}\end{array}$ & 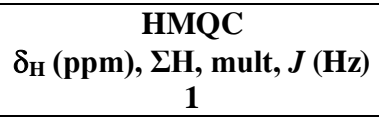 & $\begin{array}{c}\text { HMBC } \\
1\end{array}$ \\
\hline 1 & 130.2 & & & \\
\hline 2 & 132.5 & & & \\
\hline 3 & 116.0 & 6.96 & $6.95(1 \mathrm{H}, \mathrm{d}, \mathrm{J}=8.0 \mathrm{~Hz})$ & $116.0 ; 130.2 ; 161.2$ \\
\hline 4 & 161.2 & & & \\
\hline 5 & 116.0 & & & \\
\hline 6 & 132.5 & 7.79 & $7.80(1 \mathrm{H}, \mathrm{d}, \mathrm{J}=8.0 \mathrm{~Hz})$ & $132.5 ; 161.2 ; 191.0$ \\
\hline $1{ }^{\prime}$ & 191.0 & 9.82 & $9.86(1 \mathrm{H}, \mathrm{s})$ & 132.5 \\
\hline
\end{tabular}

Note: *Data source from Spectral Database for Organic Compounds SDBS No. 3444 
The bootstrap value located at the branching shows the significance of the randomized data set in predicting the same branches (González-Orozco et al. 2016). Penicillium brefeldianum has an anamorph with Penicillium dodgei (Watanabe 2010). P. brefeldianum was recently discovered from the Chinese medicinal plant Xanthium sibiricum which produces compounds eupenicinicol $\mathrm{C}$ and eupenicinicol D (Uzma et al. 2019).

The difference in antibacterial activity of endophytic fungal extracts is due to the different content of active compounds. The antibacterial activity of the endophytic fungus from $S$. zeylanicum correlated with the antibacterial activity of the host plant. The endophytic fungal extracts were more effective against Gram-positive bacteria compared to Gram-negative bacteria (Rani et al. 2017). Several previous studies showed that $S$. zeylanicum was reported to have antimicrobial activity against $P$. aeruginosa, E. coli, P. vulgaris, S. aureus, K. pneumoniae, and Bacillus subtilis (Deepika et al. 2014). The abundance of phenolic and flavonoid compounds in the $S$. zeylanicum contributes to its strong antimicrobial activity (Deepika et al. 2014; Microbiol et al. 2016; Palanisamy et al. 2011; Shilpa and Krishnakumar 2015).

A previous study by Sheng-yuan et al. (2018) succeeded in finding 11 compounds from the ethyl acetate extract of stem and leaves of Syzygium jambos, namely genin (1); 2',4 -dihydroxy-6'-methoxy-3'-methyl chalcone (2); $\quad 2^{\prime}, 4^{\prime}$-dihydroxy-6'-methoxy-3', $5^{\prime}$ dimethyldihydrochalcone (3); 6-desmethylsideroxylin (4); 5,7-dihydroxy-6,8-dimethyl-4'-methoxyflavone (5); phydroxybenzaldehyde (6); quercitrin (7); ellagic acid (8); syringin (9); glucosyringic acid (10); and adenosine (11). It was revealed that one of the compounds found in $S$. jambos was p-hydroxybenzaldehyde. This compound is also produced by the endophytic fungus SZR2. It indicates that endophytic fungi can produce compounds that are almost the same as their hosts.

\section{ACKNOWLEDGEMENTS}

The authors thank the Directorate of Research and Community Service, Ministry of Research and Technology, Indonesia, which provided research funding through Hibah Disertasi Doktor 2021, with contract no. 0116.06/UN9/SB3.LP2M.PT/2021.

\section{REFERENCES}

Ahrenfeldt J, Skaarup C, Hasman H, Pedersen AG, Aarestrup FM, Lund O. 2017. Bacterial whole genome-based phylogeny: Construction of a new benchmarking dataset and assessment of some existing methods. BMC Genomics 18 (1): 1-13. DOI: 10.1186/s12864-016-3407-6

Ancheeva E, Daletos G, Proksch P. 2020. Bioactive secondary metabolites from endophytic fungi. Curr Med Chem 27 (11): 1836-1854. DOI: 10.2174/0929867326666190916144709

Anoop MV, Bindu AR. 2015. In-Vitro anti-inflammatory activity studies on Syzygium zeylanicum (L.) DC leaves. Int J Pharm Res Rev 4 (8): 18.

Arora J, Ramawat KG. 2017. An Introduction to Endophytes. Springer, Cham. DOI: 10.1007/978-3-319-66541-2_1

DOI: $10.13057 /$ biodiv/d221051

Bhanu, Devi RC, Sabu KK. 2017. Analysis of micronutrients in Syzygium zeylanicum var. zeylanicum fruits. IJFSN 2 (4): 168-172.

Budiono B, Elfita E, Muharni M, Yohandini H, Widjajanti H. 2019. Antioxidant activity of Syzygiumsa marangense L. and their endophytic fungi. Molekul 14 (1): 48-55. DOI: 10.20884/1.jm.2019.14.1.503

Chadwick DJ, Marsh J. 2008. Bioactive compound from Plants. Wiley.

Cummings NJ, Ambrose A, Braithwaite M, Bissett J, Roslan HA, Abdullah J, Stewart A, Agbayani FV, Steyaert J, Hill RA. 2016. Diversity of root-endophytic Trichoderma from Malaysian Borneo. Mycol Prog 15 (5). DOI: 10.1007/s11557-016-1192-x

Deepika N, Saranya J, Eganathan P, Sujanapal P. 2014. Antimicrobial activity of Syzygium zeylanicum (L.) DC. and Syzygium Hemisphericum (Walp.) alston. J Biol Active Prod Nat 4 (2): 120124. DOI: $10.1080 / 22311866.2014 .890065$

Ding L, Ren L, Li S, Song J, Han Z, He S, Xu S. 2019. Production of new antibacterial 4-Hydroxy- $\alpha$-Pyrones by a marine fungus Aspergillus niger cultivated in solid medium. Mar Drugs 17 (6). DOI: $10.3390 / \mathrm{md} 17060344$

Diongue K, Bréchard L, Seck MC, Ndiaye M, Badiane AS, Ranque S, Ndiaye D. 2019. A comparative study on phenotypic versus ITSbased molecular identification of dermatophytes isolated in Dakar, Senegal. Int J Microbiol 2019. DOI: 10.1155/2019/6754058

El-hawary SS, Moawad AS, Bahr HS, Abdelmohsen UR, Mohammed R. 2020. Natural product diversity from the endophytic fungi of the genus Aspergillus. RSC Adv 10 (37): 22058-22079. DOI: 10.1039/D0RA04290K

Elfita E, Larasati JE, Widjajanti H. 2019. Antibacterial activity of Cordyline fruticosa leaf extracts and its endophytic fungi extracts. Biodiversitas 20 (12): 3804-3812. DOI: 10.13057/biodiv/d201245

Fitriarni D, Kasiamdari RS. 2018. Isolation and identification of endophytic fungi from leave and stem of Calopogonium mucunoides. J Trop Biodivers Biotechnol 3 (1): 30. DOI: 10.22146/jtbb.32477

Gao N, Shang ZC, Yu P, Luo J, Jian KL, Kong LY, Yang MH. 2017. Alkaloids from the endophytic fungus Penicillium brefeldianum and their cytotoxic activities. Chinese Chem Lett 28 (6): 1194-1199. DOI: 10.1016/j.cclet.2017.02.022

Gherbawy Y, Kesselboth C, Elhariry H, Hoffmann K. 2010. Molecular barcoding of microscopic fungi with emphasis on the mucoralean genera Mucor and Rhizopus. In: Molecular identification of fungi (pp. 213-250). Springer, Berlin, Heidelberg. DOI: 10.1007/978-3-64205042-8_11

Gonzalez-Orozco CE, Pollock LJ, Thornhill AH, Mishler BD, Knerr N, Laffan SW, Miller JT, Rosauer DF, Faith DP, Nipperess DA, Kujala H. 2016. Phylogenetic approaches reveal biodiversity threats under climate change. Nat Climate Change 6 (12): 1110-1114. DOI: 10.1038 /nclimate3126

Govindarajan M, Benelli G. 2016. $\alpha$-Humulene and $\beta$-Elemene from Syzygium zeylanicum (Myrtaceae) essential oil: highly effective and eco-friendly Larvicides against Anopheles subpictus, Aedes Albopictus, and Culex tritaeniorhynchus (Diptera: Culicidae). Parasitol Res 115 (7): 2771-2778. DOI: 10.1007/s00436-016-5025-2

Habisukan UH, Elfita E, Widjajanti H, Setiawan A, Kurniawati AR. 2021. Diversity of endophytic fungi in Syzygium aqueum. Biodiversitas 22 (3): 1129-1137. DOI: $10.13057 /$ biodiv/d220307

Hanin NA, Fitriasari PD. 2019. Identification of endophytic fungi from fruits and seeds of jambolana (Syzygium cumini L.) skeels. IOP Conf Ser: Earth Environ Sci 276 (1). DOI: 10.1088/17551315/276/1/012060

Hibbett DS, Ohman A, Glotzer D, Nuhn M, Kirk P, Nilsson RH. 2011. Progress in molecular and morphological taxon discovery in Fungi and options for formal classification of environmental sequences. Fungal Biol Rev 25 (1): 38-47. DOI: 10.1016/j.fbr.2011.01.001

Hoffmann K, Discher S, Voigt K. 2007. Revision of the genus Absidia (Mucorales, Zygomycetes) based on physiological, phylogenetic, and morphological characters; thermotolerant Absidia spp. form a coherent group, Mycocladiaceae fam. nov. Mycol Res 111 (10): 1169-1183. DOI: $10.1016 /$ j.mycres.2007.07.002

Katoch M, Pull S. 2017. Endophytic fungi associated with Monarda citriodora, an aromatic and medicinal plant and their biocontrol $\begin{array}{llll}\text { potential. Pharm Biol } 55 & \text { (1): 1528-1535. DOI: }\end{array}$ 10.1080/13880209.2017.1309054

Kothe E, Turnau K. 2018. Editorial: mycorrhizosphere communication: mycorrhizal fungi and endophytic fungus-plant interactions. Front Microbiol 9 (DEC): 1-4. DOI: 10.3389/fmicb.2018.03015 
Kumar V, Soni R, Jain L, Dash B, Goel R. 2019. Endophytic Fungi: recent advances in identification and explorations. Adv Endophytic Fungal Res: 267-281. DOI: 10.1007/978-3-030-03589-1_13

Kuswytasari ND, Kurniawati AR, Alami NH, Zulaika E, Shovitri M, Oh KM, Puspaningsih NN, Ni'matuzahroh NM. 2019. Plastic degradation by Coriolopsis byrsina, an identified white-rot, soil-borne mangrove fungal isolate from Surabaya, East Java, Indonesia. Biodiversitas 20 (3): 867-871. DOI: 10.13057/biodiv/d200334

Li SJ, Zhang X, Wang XH, Zhao CQ. 2018. Novel natural compounds from endophytic fungi with anticancer activity. Eur J Med Chem 156 316-343. DOI: 10.1016/j.ejmech.2018.07.015

Savani AK, Rajashekar M. 2018. Inhibitory effect of endophytic Trichoderma species against Colletotrichum leaf spot of clove and its compatibility with fungicides. Progressive Res - An Int 11 (4) : 24602465 .

Mayasani N, Hikmahtunnazila H, Lestari W, Roanisca O. 2019. Kajian fitokimia daun Syzygium zeylanicum menggunakan metode Microwave Assisted Extraction (MAE). Prosiding Seminar Nasional Penelitian and Pengabdian Pada Masyarakat 3: 1-4. [Indonesian]

Zouhir A, Taieb M, Lamine MA, Cherif A, Jridi T, Mahjoubi B, Mbarek S, Fliss I, Nefzi A, Sebei K, Hamida JB. 2016. Antistaphybase: database of Antimicrobial Peptides (AMPs) and Essential Oils ( EOs ) against Methicillin-Resistant Staphylococcus aureus ( MRSA ) and Staphylococcus aureus. Arch Microbiol 199 (2): 215-222. DOI: 10.1007/s00203-016-1293-6

Wang SL, Nguyen TH, Doan CT, Tran TN, Kuo YH, Nguyen QV, Nguyen AD. 2019. New indications of potential rat intestinal $\alpha$ glucosidase inhibition by Syzygium zeylanicum (L.) and its hypoglycemic effect in mice. Res Chem Intermediates 45 (12): 6061 6071. DOI: 10.1007/s11164-019-04019-4

Nomi Y, Shimizu S, Sone Y, Tuyet MT, Gia TP, Kamiyama M, Shibamoto T, Shindo K, Otsuka Y. 2012. Isolation and antioxidant activity of Zeylaniin A, a new macrocyclic ellagitannin from Syzygium zeylanicum leaves. J Agric Food Chem 60 (41): 10263 10269. DOI: $10.1021 /$ jf302977n

Palanisamy UD, Ling LT, Manaharan T, Appleton D. 2011. Rapid isolation of geraniin from Nephelium lappaceum rind waste and its anti-hyperglycemic activity. Food Chem 127 (1): 21-27. DOI 10.1016/j.foodchem.2010.12.070

Pitt, John I, Hocking AD. 2009. Fungi and Food Spoilage (Google EBook). New York, Springer: 536. DOI: 10.1007/978-0-387-92207-2

Ploetz RC, Pérez-Martínez JM, Palmateer AJ, Tarnowski TL. 2009. Influence of temperature, light intensity, and isolate on the development of Neofusicoccum parvum-induced dieback of Eugenia, Syzygium paniculatum. Plant Dis 93 (8): 804-808. DOI: 10.1094/PDIS-93-8-0804

Potshangbam M, Devi SI, Sahoo D, Strobel GA. 2017. Functional characterization of endophytic fungal community associated with
Oryza Sativa L. and Zea Mays L. Front Microbiol 8 (MAR): 1-15. DOI: $10.3389 /$ fmicb.2017.00325

Rani R, Sharma D, Chaturvedi M, Yadav JP. 2017. Antibacterial activity of twenty different endophytic fungi isolated from Calotropis procera and time-kill assay. Clin Microbiol 6 (3): 280. DOI: 10.4172/23275073.1000280

Rashmi M, Kushveer JS, Sarma VV. 2019. A worldwide list of endophytic fungi with notes on ecology and diversity. Mycosphere 10 (November): 798-1079. DOI: 10.5943/mycosphere/10/1/19

Schueffler A, Anke T. 2011. Antimicrobial compounds from tree endophytes. In: Endophytes of Forest Trees. Springer, Dordrecht. DOI: 10.1007/978-94-007-1599-8_17

Sheng-yuan ZH, Yuan-bei ZH, Da-du LI, Ming ZH, Jun-fang LI, Zhenghui WE, Hua NI. 2018. Chemical constituents from $\alpha$-Glucosidase inhibitory active part in stems and leaves of Syzygium jambos. Nat Prod Res Dev 30 (1): 1950-1956.

Shilpa KJ, Krishnakumar G. 2015. Nutritional, fermentation and pharmacological studies of Syzygium caryophyllatum (L.) alston and Syzygium zeylanicum (L.) DC fruits. Cogent Food Agric 1 (1): 1018694. DOI: 10.1080/23311932.2015.1018694

Shofiana RH, Sulistyowati L, Muhibuddin A. 2015. Eksplorasi jamur endofit dan khamir pada tanaman cengkeh (Syzygium aromaticum) serta uji potensi antagonismenya terhadap jamur akar putih (Rigidoporus microporus). Jurnal HPT 3 (1): 75-83. [Indonesian]

Singh P, Sharma A, Bordoloi M, Nandi SP. 2020. Molecular identification of endophytic fungi isolated from medicinal plant. Biointerface Res Appl Chem 10: 6436-6443. DOI: 10.33263/BRIAC105.64366443

Tamura K, Stecher G, Peterson D, Filipski A, Kumar S. 2013. MEGA6: Molecular Evolutionary Genetics Analysis Version 6.0. Mol Biol Evol 30 (12): 2725-2729. DOI: 10.1093/molbev/mst197

Tayung K, Barik BP, Jha DK, Deka DC. 2011. Identification and characterization of antimicrobial metabolite from an endophytic fungus, Fusarium solani isolated from bark of Himalayan Yew. Mycosphere 2 (3): 203-213.

Uzma F, Mohan CD, Siddaiah CN, Chowdappa S. 2019. Endophytic fungi: Promising source of novel bioactive compounds. In: Advances in endophytic fungal research. Springer, Cham. DOI: 10.1007/978-3030-03589-1_12

Walsh TJ, Hayden RT, Larone DH. 2018. Larone's Medically Important Fungi: A Guide to Identification. John Wiley \& Sons. DOI: 10.1128/9781555819880

Wang Y, Xu L, Ren W, Zhao D, Zhu Y, Wu X. 2012. Bioactive metabolites from Chaetomium globosum L18, an endophytic fungus in the medicinal plant Curcuma wenyujin. Phytomedicine 19 (3-4): 364-368. DOI: 10.1016/j.phymed.2011.10.011

Watanabe T. 2010. Pictorial Atlas of Soil and Seed Fungi. CRC Press. DOI: 10.1201/EBK1439804193 